\title{
Action and Diagnosis Protocol for Musculoskeletal Tumors in the Tumor Service of the CCOI Frank Pais
}

\author{
Carlos Gonzalez de Varona ${ }^{1}$, Alicia Tamayo Figueroa*2, Ragnar Calzado Calderon², Vilma \\ Rondon Garcia ${ }^{3}$, Maria Emilia Santiesteban Fuentes ${ }^{4}$ and Jose Enrique Perez Gonzalez ${ }^{1}$ \\ ${ }^{1}$ Asistent profesor, Medicine integral general and Ortopedic/traumatology first degree, Cuba \\ ${ }^{2}$ Auxiliar profesor, Ortopedic/traumatology second degree, Cuba \\ ${ }^{3}$ Radiology Department second degree, Cuba \\ ${ }^{4}$ Internal medicine/intensive terapy master, Cuba \\ *Corresponding author: Alicia Tamayo Figueroa, Auxiliar profesor, Ortopedic/traumatology second degree, Cuba
}

$\begin{array}{lll}\text { ARTICLE INFO } & & \text { ABSTRACT } \\ \begin{array}{l}\text { Received: May 11, } 2021 \\ \text { Published: May 18, } 2021\end{array} & \begin{array}{l}\text { Keywords: Action Guide; Bone Tumors; Musculoskeletal Oncology; Orthopedic Sur- } \\ \text { geons; Radiologists; Clinicians; Pathologists }\end{array}\end{array}$

Citation: Carlos Gonzalez de V, Alicia Tamayo F, Ragnar Calzado C, Vilma Rondon G, Maria Emilia Santiesteban F, Jose Enrique Perez G. Action and Diagnosis Protocol for Musculoskeletal Tumors in the Tumor Service of the CCOI Frank Pais. Biomed J Sci \& Tech Res 35(5)-2021. BJSTR. MS.ID.005770.

\section{Introduction}

Bone tumors are not common. Statistics indicate an incidence of ten cases of malignant primary bone tumor per million inhabitants per year, while benign tumors are much more frequent. Among benign bone tumors, the most frequent are: Osteochondroma, Enchondroma, Giant Cell Tumor (GCT) and Osteoid Osteoma. In the case of the malignant, the most frequent is multiple myeloma followed by Osteosarcoma, Chondrosarcoma and Ewing's sarcoma. In pseudotumor lesions, the most frequent are: solitary bone cyst, aneurysmal bone cyst and metaphyseal fibrous defect. Musculoskeletal oncology is a multidisciplinary specialty for which the work in our service has not been possible without the joint effort and dedication of orthopedic surgeons, radiologists, clinicians and pathologists.

\section{Development}

Knowing how to diagnose in time and knowing how to guide a patient is on countless occasions the salvation of a life or the preservation of a part of the human body. The simplest classification in terms of tumors, as we all know, is benign or malignant, but as studies on tumors have developed, it has become known of the need for a classification more in line with the current situation in the study of tumors and After multiple attempts we have that the WHO for practical purposes recommends that the following be used [1-10]. 


\section{Eye Put Who Classify Table}

\section{Diagnostic Procedures}

\section{Lab tests:}

a) Complete blood count with erythrocyte sedimentation.

b) Creatinine, Transaminases, uric acid

c) Glycemia (if necessary).

d) Serology.

e) HIV.

f) C-reactive protein

g) Calcium and phosphorus in the blood.

h) Alkaline phosphatase (has prognostic value in tumors that form bone tissue.

i) Acid phosphatase and PSA (if prostate cancer is suspected).

j) Protein electrophoresis, Bence Jones protein, Kappa Lambda Index and medullogram (if multiple myeloma is suspected).

k) Functional thyroid studies [11-20].

\section{Imaging Diagnosis}

A. Conventional simple radiology in at least two views. In these you can define:

1. Numbers of bone lesions.

2. Location and situation.

3. Effect of the injury on the bone.

4. Periosteal reaction.

5. Special features.

B. Computerized Axial Tomography (CT): In these the calcifications are demonstrated, the periosteal reaction is appreciated, the extension of the lesion can be assessed, and it is useful for staging as well as digital reconstructions of the injury site can be performed.

C. Angiography: it is used little, but it is useful in vascular lesions, to carry out embolization's, to determine very vascular areas related to the tumor.

D. Scintigraphy: In our environment with Technetium 99 dysphonate and MIBI. It is used to track hidden tumors, look for metastases, and evaluate tumor activity after surgery.

E. Magnetic resonance: It is the most useful technique to appreciate the tumor activity and the intramedullary extension and to soft tissues of the tumor.
F. Biopsy: necessary for the definitive diagnosis [21-30].

a) Closed by needle puncture that can be:

i. BAAF (Fine Needle Aspiration Biopsy)

ii. Needle.

I. Trocar.

b) Openly (with general anesthesia and in a regulated operating room) and can be of two types:

I. Incisional: a fragment of the tumor is taken.

II. Excisional: the entire tumor is removed and is indicated in: benign tumors, malignant tumors in which this is the treatment and in painful metastases.

III. Considerations to take into account when performing the biopsy:

a) Do not make transverse incisions (if the tumor is malignant then it will be necessary to remove the entire incision)

b) Do not go through several compartments (for the same reason above)

c) Carry out careful hemostasis.

d) Remove ischemia before closing.

e) Place the drain if necessary, through the incision.

f) Use a compression bandage.

g) Send samples to microbiology if associated septic process is suspected.

G. Staging (the Enneking system is used)

1. G: histological grade of malignancy.

2. G 0: benign.

3. G 1: low grade malignant.

4. G 2: high grade malignant.

A. T: tumor location.

B. T 0: intracapsular.

C. T 1: intercompartmental. Extracapsular

D. T 2: extra-compartmental.

a) M: presence of metastasis.

b) M 0: no metastasis.

c) M 1: metastasis.

\section{Surgical Procedures}

1. Intralesional resection (through the tumor) and 
subsequent treatment (curettage and filling with autologous cancellous bone or Bench, hydroxyapatite and PMMA.)

2. Marginal resection (by the reactive zone of the tumor).

3. Wide resection: resection of the entire tumor with a small margin of normal tissue.

4. Radical resection: Amputation of the limb to the level that is necessary as well as the amputation of fingers and joints in the beam, disarticulation in both the upper and lower limbs.

5. Placement of tumor prostheses for proximal femur and knee tumors.

6. Chemotherapy and radiotherapy by the Oncology service [31-40].

\section{Action for the Most Frequent Tumors in the Service}

\section{Most Frequent Benign Tumors}

A. Osteochondroma: It is carried out en bloc resection including the base to avoid recurrences when:

1. Compressive symptoms appear.

2. Increase in size after the physis is closed.

3. Appearance of intense pain.

4. Presence of calcifications inside [41-50].

B. Osteoid osteoma: The treatment of choice is surgical. If it is stage 1 and pain is controlled with analgesics, observation is recommended and if it is stage 2 and 3 , en bloc excision of the tumor including the niche will be performed.

C. Enchondroma: The treatment of choice is surgical by curettage and preferably filling with coral hydroxyapatite with adequate granulometry.

\section{Most Frequent Malignant Tumors}

A. Osteosarcoma: Radical surgery with preoperative polychemotherapy is recommended for 8 to 12 weeks, which eliminates up to $90 \%$ of micro-metastases and sterilizes the reactive area. After surgery, chemotherapy is continued for 12 to 24 weeks.

B. Giant Cell Tumor: The treatment of GCT is controversial and controversial and includes various options such as:

1. Curettage and graft of autologous or homologous bone.

2. Curettage and insertion of polymethylmethacrylate (PMMA).

3. Cryotherapy after curettage.

4. Curetting and washing the cavity with phenol, alcohol, Zinc chloride and hydrogen peroxide, milling the cavity and inserting PMMA or bone graft.

5. En bloc resection and bone transport with external fixator or tumor prosthesis.

6. Radiotherapy.

7. Embolization of the vessels that feed it [51-60]

In our environment we do not use cryotherapy or lavage of the cavity, radiotherapy is in disuse because it produces sarcomatous degeneration of the tumor and we have no experience in embolization of the vessels.

En bloc resection with transportation guarantees a low incidence of recurrence but causes multiple complications such as infection, graft resorption, pseudoarthrosis, delayed union and fractures: a very long period of time is also required for the patient's recovery. In the case of en bloc resection and insertion of a tumor prosthesis, it is only possible when the GCT is located in the proximal epiphysis of the femur and knee.

We usually use curettage with PMMA insertion, which controls recurrences in between 80 and $90 \%$ of cases with much better results than bone graft insertion and also facilitates early ambulation, immediate rehabilitation and social incorporation of the patient in a shorter period of time. We have used amputation in those cases of malignant GCT with soft tissue infiltration or those located in short bones that have not been feasible for another surgery and due to the high risk of metastasizing [61-71].

C. Chondrosarcoma: They are not chemo or radiosensitive, they only require surgical treatment:

1) En bloc resection of the tumor and bone transport with external fixator or insertion of a tumor prosthesis.

2) Radical surgery:

I. Amputation.

II. Dislocation.

3) Ewing's sarcoma: Chemotherapy + radiotherapy.

4) Surgery only in sacrificial bones associated with preoperative chemotherapy to decrease the size of the tumor and make surgery easier.

5) Survival at 5 years can be as high as $60 \%$.

D. Multiple myeloma: it is the most common primary malignant bone tumor.

It is the responsibility of Internal Medicine and Hematology, if there are pathological fractures, surgical stabilization by the orthopedic will be needed.

E. Pseudotumor lesions 
1. Solitary Bone Cyst: Generally, there is no urgency for treatment, it is important to explain to the parents that it is a benign lesion and the dangers of a fracture or growth retardation if the lesion involves the physis. If a pathological fracture occurs, it is preferable to wait for consolidation since in some cases this causes the cyst to heal.

a) Curettage and filling: With caution if the lesion is adjacent to the physis.

b) Non-ossifying Fibroma or Metaphyseal Fibrous Defect: Observation

c) It is only operated if it is symptomatic or has a risk of fracture (more than 50 to $75 \%$ of the diameter of the bone)

d) Treatment consists of curettage and filling.

e) Aneurysmal Bone Cyst: Curettage and filling. In our experience we want to point out that the remote but present possibility of the installation of a tumor of another type, including a malignant one, on this type of lesion must be taken into account, which requires strict monitoring.

\section{Conclusion}

Establish a protocol for diagnosis and action in the event of a suspected tumor that allows us to evaluate the patient as soon as possible to avoid unnecessary sacrifices. Trains orthopedic surgeons in the management of tumor lesions. Request the competition for related specialties whenever necessary, knowing in advance that teamwork is essential in this area.

\section{Conflict of Interest}

None.

\section{References}

1. Ando K, Arslandemir C, Bell WC (2010) Bone Cancer. Progression and Therapeutic Approaches. $1^{\text {st }}$ (Edn.) Elsevier Inc., United States of America.

2. (2014) Statistical health yearbook. MINSAP.

3. Aegerter E, Kirkpatrick JA (1988) General considerations about Tumors. $1^{\text {st }}$ (Edn.), Havana: Technical Scientific Ed.

4. Aguilera A, Torrealba R (1990) Surgical treatment of bone tumors and other pathologies with allografts. Rev Cub Ortopedia y Traumatol 5(10): 97-112.

5. Alleyne G (2006) Clinical Oncology. $2^{\text {nd }}$ (Edn.), Murphy GP, Washington, USA.

6. Fletcher C, Mertens F (2002) World Health Organization Classification of Tumors. Pathology and Genetics of Tumors of Soft Tissue and Bone. $1^{\text {st }}$ (Edn.) Lyon: IARC Press, France.

7. Álvarez López Alejandro, García Lorenzo Yenima, Puentes Álvarez Antonio, García Lorenzo Maruldis (2010) Osteosarcoma: current approach. AMC [magazine on the Internet] 14 (5).

8. Álvarez López Alejandro, García Lorenzo Yenima, Rodríguez Rodríguez Eugenio, Baesso Everson (2002) Ten-year behavior of osteochondroma in a pediatric hospital. Rev Cubana Ortop Traumatol [magazine on the Internet] 16 (1-2): 61-64.
9. Antman K, Crowley J, Balcerzark S, Kempt R, Weiss R, et al. (1998) A southwest oncology group phase II study of doxorubicin, dacarbazine, ifosfamide and mesna in advanced osteosarcoma, Ewing's sarcoma and Rhabdomyosarcoma. Cancer 82 (7): 1288-1295.

10. Bakemeier RF (1980) Principles of Oncology Medicine and Cancer Chemotherapy. $1^{\text {st }}$ (Edn.), New York: Rochester, USA.

11. Benjamin A, Alman F, G Barr, John C (2006) Pediatric Bone and Soft Tissue Sarcomas. $1^{\text {st }}$ (Edn.) Berlin: Springer-Verlag.

12. Bickels J, Jelinek J, Shmookler B (2001) Biopsy of Musculoskeletal. Philadelphia: Jaffe HL.

13. Buckely JD, Pendergrass TW, Bucley CM, Pritchard DJ, Nesbil ME, et al. (1998) Epidemiology of osteosarcoma and Ewing's sarcoma: a study of 305 cases by the children's cancer group. Cancer 83(7): 1440-1448.

14. Canale T (2013) Campbell Cirugía Ortopédica. 12 $2^{\text {th }}$ (Edn.), Elsevier, Boston, USA.

15. Remotti F, Feldman F (2012) Nonneoplastic lesions that simulate primary tumors of bone. Archives of Pathology \& Laboratory Medicine 136(7): 772-788.

16. Candebat R, Candebat RR, Mauri Pérez O, Sosa M, Rajadel R, et al. (2012) Fibroma desmoplásico de la columna lumbar. Rev Cubana Ortop Traumatol [revista en la Internet] 26(1).

17. Holzapfel B, Lüdemann M, Holzapfel D, Rechl H, Rudert M (2012) Open biopsy of bone and soft tissue tumors: guidelines for precise surgical procedures. Operative Orthopädie Und Traumatologie 24(4-5): 403415.

18. Gaynor JJ, Tan CC, Casper E (1992) Refinement of clinico pathologic staging for localized soft tissue sarcome: study of 423 adults. J ClinOncol 10(2):1317-1319.

19. González I, Pedraza NE, Franco A (2012) Informe anatomo-patológico de un tumor óseo de células gigantes en localización no habitual. Acta Médica del Centro [revista en la Internet] 6(1).

20. Eeing D (2008) Assessment of interobserver variability and histological parameters to improve reliability in clasification and grading of central cartilaginous tumors, $2^{\text {nd }}($ Edn.), Berlin: Springer-Verlag.

21. Enneking WF, Conrad EV (1989) Common bone tumors. Summit CIBA. Geigy 2(45).

22. Enneking WF, Wolf RE (1996) The staging and surgery of musculoskeletal neoplasm. Clin Orthop 27(1): 433-481.

23. Enneking WF (1987) A system of staging musculoskeletal neoplasms. Clin Oncol (1)1: 97-109.

24. Enneking WF (1983) Musculoskeletal Tumor Surgery, $1^{\text {st }}$ (Edn.), Enneking WF, New York, USA.

25. Eyesan S, Idowu O, Obalum D, Nnodu O, Abdulkareem F (2011) Surgical consideration for benign bone tumors. Nigerian Journal of Clinical Practice [revista en la Internet] 14(2): 146-150.

26. Fleming ID, Cooper JS, Henson DE (1997) Cancer Staging Manual. $5^{\text {th }}($ Edn.), Lippincott-Raven, Philadelphia, Pennsylvania.

27. Wahab Vargas RA, Figueroa Castillo F, Sosa Mendoza P, Useche Medina ND, Ortiz Barrios G (2003) Incidence of bone tumors in the pathology department of the Central University Hospital "Antonio María Pineda."1997. Postgraduate Medical Bulletin. UCLA XIX (1): 27-33.

28. Kissane M John (1986) Anderson Pathology, $8^{\text {th }}$ (Edn.), Buenos Aires: Médica Panamericana, pp: 2105-2147.

29. Remonet L, Esteve J, Bouvier MA (2003) Cancer Incidence and mortality in France over the period 1978-2000. Rev Epidemiol Sante Publique 51: 3-30. 
30. Hashimoto KO, Hatori M, Hosaka M (2006) osteosarcoma arising from giant cell tumor of bone. Ten years after primary surgery: A case report and review of literature. Tohoku J Exp med 208: 157-162.

31. Grimer RJ, Bielack S, Flege S (2005) Periosteal osteosarcoma a Eupropean review of outcome. Eur J cancer 41: 2806-2811.

32. Hatori M, Watanabe M, Kotabe H, Kokubun S (2006) Condrosaexhoma of the ring finger. A case report and review of the literature. Tohoku J Exp Med 208: 275-281.

33. Katchy KC, Ziad F, Añexander S, Gad H, Adbel Motaál M (2005) Malignant bone tumor in Kuwait a 10-year clinicopathological study. Int orthop 29 (6): 406-411.

34. Valdespino Gómez VM, Cintra mc Glone E, Figueroa Beltrán MA (1990) Bone tumors Prevalence Gac Med Mex 126: 325-334.

35. López VI, Grande GA, Siez Gañan L, Zorrilla TB (2005) Cancer mortality in children and adolescents in the community of Madrid 1977-2001. An pediatr 62: 420-426.

36. Rech A, castro CG, Mattei J (2004) Clinical features in osteosarcoma and prognostic implications. J Pediatr 80 (1): 65-70.

37. Guo W, Xu W, Huvos AG, Healy JH, Feng C (1999) Comparative frequency of bone sarcomas among different racial groups. Chin Med J 112: 11011104 .

38. Ferris TJ, Turnero BO, Garcia AJA, Morales CL (2005) Risk factors for pediatric malignant bone tumors. An pediatr 63 (6): 537-547.

39. Juárez Ocaña S, González Miranda G, Mejía Arangure JM (2004) Frequency of cancer in children residing in Mexico City and treated in the hospitals of the Instituto Mexicano del Seguro Social (1996-2001). BMC cancer [Revista en la Internet] 4: 50.

40. Fajardo Gutiérrez A, Sandoval Mex AM, Mejia Arangure JM, Rendón Macías ME (2002) Clinical and social factors that affect the time to diagnosis of mexician children with cancer. Med Pediatr Oncol 39: 25-31.

41. Arndt CAS, Crist WM (1999) Common Musculoskeletal tumors of childhood and adolescence. N Engl J Med 341: 342-352.

42. Yücetürk G, Sabah D, Keçeci B, Kara AD, Yalçinkaya S (2011) Prevalence of bone and soft tissue tumors. Acta Orthop Traumatol Turc [Revista en la Internet] 45(3):135-143.

43. Schajowicz F, Sissons H., Sobin L (2005) The World Health Organization's Histologic Classification of Bone Tumors. Rev Cancer 5:1208-1214.

44. Kumar, Abbas F (2005) Structural and functional pathology. $7^{\text {th }}$ (Edn.), Ed. Elservier, pp:1297-1299.

45. Sepúlveda Oyervides Victor Manuel (2008) Malignant Bone Tumors: Precision Diagnosis. Ortho-tips 4(2).

46. Torrijos Eslava A, Hernández Sanz A (2006) Diagnostic protocol for osteoblastic and osteolytic lesions. Medicine 9 (60): 3922-3926.

47. Sánchez-Torres LJ, Santos-Hernández M (2012) The art of diagnosing bone tumors. Acta Ortopédica Mexicana 26 (1): 57-65.

48. Pereda 0, Rumbaut M, González R (2004) Coral hydroxyapatite in treatment of tibia fractures. Medical advances XI (38): 61-64.

49. Rodríguez Rodríguez Eugenio Isidro, Arredondo Reyes Reydy, López Marrero Noelio, Fernández García Giselle, Taura Suárez Leonardo (2014) Incidence of tumors and bone pseudotumor lesions in children. Medical Archive of Camagüey 18 (5): 498-506.

50. Miralles Rodrigo. More frequent tumors in children. Children's Orthopedics Orthopedic Surgery and Traumatology in less developed areas.

51. Fierro Velazco, Francisco Javier (2008) Frequency of primary bone tumors observed in bone biopsies obtained in two clinical centers in the City of Guadalajara. [Thesis]. Guadalajara: University Center for Biomedical Research. University of Colima, Mexico.
52. Terracini B, Maule MM (2007) A etiological clues from the descriptive epidemiology of childhood acute lymphatic leukemia and other malignancies. J Epidemiol Community Health 61: 180-181.

53. Taquechel Candebat O, Corral Pacheco N, Rodríguez Moreno R, Legrá Rodríguez, Verdecia Jarque (2002) Primitive bone tumors in children. MEDISAN [series on the Internet] 6 (1): [approx. 5 p.]

54. Peris Bonet R, Giner Ripoll B (2005) Epidemiology of childhood cancer. In: Madero López L, Muñoz Villa A, editors. Pediatric Hematology and Oncology, 2nd (Edn.), Madrid: Ergon, pp: 227-238.

55. Hoyos Z, Flores R, Rodríguez A, Muñoz C (2010) Central osteoma in mandibular condyle Treatment: Report of a case. Rev Mex Cir Bucal y Maxil 6 (2): 61-65.

56. Dalambiras S, Boutsioukis C, Tilaveridis I (2005) Peripheral osteoma of the maxilla: report of an unusual case. Oral Surg Oral Med Oral Pathol Oral Radiol Endod 100 (1): e19-24.

57. Izquierdo Hernández B, Mayayo Sinués E, Crespo-Rodríguez AM (2008) Imaging diagnosis of intra-articular osteoid osteoma. Rev esp cir orthop Trauma 52: 194-198.

58. Hatori M, Watanabe M, Hosaka M, Sasano H, Narita M, et al. (2009) A classic adamantinoma arising from osteofibrous dysplasia-like adamantinoma in the lower leg: a case report and review of the literature. Tohoku J. Exp. Med (1): 53-59.

59. Soheyl Sheikh, Shambulingappa Pallagatti, Isha Singla, Aman Kalucha (2011) Desmoplastic Ameloblastoma: A Case Report J Dent Res Dent Clin Dent Prospect 5(1): 27-32.

60. Yin B, Liu L, Li YD, Geng DY, Du ZG (2011) Retroperitoneal hemangiopericytoma: case report and literature review. Chinese Medical Journal 1:155-156.

61. Gac E Patricio, Seymour M Camila, Klein P Eulin, Cabané T Patricio, Segura H Paula, et al. (2013) Hemangiopericitoma: reporte de 3 casos. Rev Chil Cir 65(2): 172-176.

62. Cade S (1990) Osteogenic sarcoma. A study based on 133 patients. J R Coll Surg 1(2): 79-111.

63. Bone BL, Evans HL (1990) Osteosarcoma practice of clinicopathologic of 26 cases. Cancer 65: 27-62.

64. Muscolo DL, Farfalli Germán L, Aponte Tinao Luis, Ayerza Miguel A (2009) Update on osteosarcoma. Rev Asoc Argent Orthop Traumatol 74 (1): 86-101. Available at:

65. Anderson ME, Randall RL, Springfield DS, Gebhart MC (2014) Sarcomas of bone. In: Niederhuber JE, Armitage JO, Doroshow JH, Kastan MB, Tepper JE, eds. Abeloff's Clinical Oncology, $5^{\text {th }}$ (Edn.), Pa: Elsevier, Pennsylvania.

66. Escarpanter Buliés IC, Martínez Cutiño A, Gutiérrez Guillén MA, Morales Jiménez LM (2012) Clinical case. Tumor of the right femur. Review of the topic and presentation of a case.

67. Melo GI, Martinez CV (2005) Chondroid bone tumors: chondromas versus conventional chondrosarcomas. Rev Chil Radiol 11 (4): 170-178.

68. Greenspan A, Remagen W (2002) Tumors of bones and joints, $1^{\text {st }}$ (Edn.), Marban, Spain, pp: 59-120.

69. Damron T, Beauchamp C (2013) Soft-tissue lumps and bumps. I Bone Joint Surg Am [magazine on the Internet] 85 (6): 1142-1155.

70. Rojas C Raúl, García B Cristián, Parra R Dimitri, Solar G Antonieta, Oyanedel Q Roberto, et al. (2005) Bone involvement in Langerhans cell histiocytosis in children: simple radiological study. Clinical presentation and radiological diagnosis. Rev chil Radiol 11(3): 116-121.

71. Azouz EM, Sargal G, Rodríguez MM, Podda A (2005) Langerhans cell histiocytosis: pathology, imaging and treatment of skeletal involvement. Pediatr Radiol 35: 103-115. 
ISSN: 2574-1241

DOI: 10.26717/BJSTR.2021.35.005770

Alicia Tamayo Figueroa. Biomed J Sci \& Tech Res

(c) (?) This work is licensed under Creative

Submission Link: https://biomedres.us/submit-manuscript.php



